Article

\title{
Leadership and Organizational Culture in the Sustainability of Subsistence Small Businesses: An Intellectual Capital Based View
}

\author{
Carlos M. Jardon ${ }^{1,2}, * \mathbb{C}$ and Xavier Martínez-Cobas ${ }^{3}[$ \\ 1 Department of Applied Economics-ECOBAS, University of Vigo, 36310 Vigo, Galicia, Spain \\ 2 National Research University Higher School of Economics, Myasnitskaya Ulitsa 20, 101000 Moskva, Russia \\ 3 Department of Financial and Accounting-ECOBAS, University of Vigo, 36310 Vigo, Galicia, Spain \\ * Correspondence: cjardon@uvigo.es; Tel.: +34-646-730-741
}

Received: 14 May 2019; Accepted: 18 June 2019; Published: 25 June 2019

check for updates

\begin{abstract}
The concept of leadership is complex and has been studied from multiple approaches, especially from the psychological field and from the field of management. Small businesses created as way of subsistence for the entrepreneur and their family present a limited leadership. The cultural traditions of the forestry industry are based on the culture and indigenous know-how of the territory, especially affecting small timber businesses, the small businesses working in timber activities. This paper analyzed the interrelation between culture and leadership in the process of generating performance from sustainable competitive advantages using partial least squares (PLS) techniques. The results show that culture and leaderships are sources of competitive advantage in subsistence small businesses, but culture does not generate competitiveness directly; an organizational culture needs to act through entrepreneurial leadership.
\end{abstract}

Keywords: organizational culture; leadership; competitive advantages; Latin America; subsistence small businesses

\section{Introduction}

To alleviate poverty in the poorest areas of developing countries, people usually create businesses as a means of support for their families [1,2]. The motivation behind these businesses mixes a need with the search for opportunities [3], and, usually, they are not oriented toward growth, but only to satisfy family needs. These businesses are defined as subsistence small businesses (SSBs).

Businesses, especially in developing countries, need human capital to grow [4]. An essential aspect of human capital is leadership, especially in SSBs, because their success rate is usually very small and is conditioned by the style of leadership [5].

The concept of leadership is complex and has been studied from multiple approaches, especially from the psychological field and from the field of management. This multiplicity of approaches has led in practice to an extensive leadership typology more or less accepted in the management literature. For example, Brown \& Treviño (2006) [6] compare ethical leadership with authentic leadership, spiritual leadership, and transformational leadership, while Bryant (2003) [7] compares the latter with transactional leadership. Hitt \& Duane (2002) [8] have studied strategic leadership, and Jing (2018) [9] mentions four leadership types: classic leadership, transactional leadership, visionary leadership, and organic leadership. Another publication [10] lists 29 categories in a survey about leadership or theories of leadership. This variety of typologies and approaches indicates that there is no single concept of leadership as assumed by the literature, and that, even within the different typologies, different behaviors of the leader are possible. However, in no case has leadership has been analyzed 
from an intellectual capital-based view [11], although different authors have included it in their lists of human capital of a company [12-14].

The intellectual capital approach suggests that intangible assets, including leadership and culture, are a source of value for the company that allows it to develop the sustainable competitive advantages necessary for the sustainability of SSBs $[15,16]$. In small businesses, the leadership ability of the entrepreneur is essential for the growth of the company, as the entrepreneur is usually also the owner-manager. On the one hand, its human capital is essential to create competitive advantage [17], since the entrepreneur manages the company's resources and organizes how they should be combined to improve competitiveness. On the other hand, the entrepreneur chooses the strategy that the company must follow [8]. Although various previous papers have analyzed how leadership has an effect on the company's results and how it can be used to generate competitive advantages, it is not common to study leadership as a strategic resource, that is, as a source of competitive advantage.

Leadership in SSBs is limited, since entrepreneurs tend to have little training, and business knowledge is usually based on experience, but not on strategic approaches. In addition, these small businesses are usually formed by family members of the entrepreneur, so their leadership will be closely associated with the prestige that the entrepreneur has within the family. As a result, the effect of the entrepreneur's leadership on competitive advantages may be questioned.

The first aim of this paper is to analyze the impact of leadership on the competitive advantages of SSBs from an intellectual capital-based view.

The culture belongs to the structural capital of the company [18]. Previous studies on the relationship between culture and competitiveness have been inconclusive [19]. While a series of authors have pointed out a direct effect [20,21] or an indirect effect [22], others found no relationship [23], and others indicate a mixture of results $[24,25]$. The specific characteristics of SSBs suggest a special interest in analyzing this topic in these companies, contributing ideas to the general discussion. This is the second aim of this paper.

Bruhn, Karlan, and Schoar (2010) [26] suggest the need for changes in SSBs to enable their growth. Leadership and culture are essential aspects of the change process [27]. However, the relationship between leadership and culture is not clear, and there are two contradictory trends explaining this relationship [28]. The functionalist trend suggests that leaders are those that generate cultural change [29], while the anthropological trend suggests that leaders are part of the culture in which they move, and that the culture conditions leadership [30]. Previous studies have shown that the functionalist current tends to be more common [31,32]. However, in the case of small subsistence enterprises, which are highly associated with the territory, it seems that it is the anthropological current that has the most significance. The third aim of this paper is therefore to test the different visions about the relationships between culture and leadership in SSBs.

The interrelation between culture and leadership will possibly condition the obtaining of sustainable competitive advantages. For example, Sarros et al. (2011) [28] suggest a mediation effect of organizational culture on the effect of leadership in the performance of non-profit and profit organizations. Vallejo-Martos (2011) [33] introduced the transformational leadership inside of the organizational culture, analyzing its effects on performance. Yiing and Ahmad (2009) [34] studied the moderating effects of organizational culture on the relationships among leadership behavior and variables of performance in Malaysia. To evaluate the moderation or mediation effects between culture and leadership on performance is the last aim of this paper. The study is integrated into the intellectual-capital-based-view, since it highlights how aspects of human capital and structural capital generate sustainability $[15,18]$ in SSBs.

This study analyzes these topics in small forestry businesses in the province of Misiones (Argentina), since forestry is an important activity in this region and has a marked culture that eliminates the influence of other industrial cultures. Forest SSBs are extremely common in this industry, especially in developing countries [35]. They are usually dispersed throughout the territory, with "a strong sense of attachment to their particular place" [36], seeking proximity to natural resources, an aspect that they take advantage 
of. This closeness to the territory and wide dispersion mean that culture is even more important. In fact, local knowledge and local culture are essential for the development of forestry $[37,38]$. Within the forestry industry, the most important activity is that related to timber production.

Knowledge about the interaction between culture and leadership will result in actions to improve the competitiveness of SSBs [39], both from the point of view of management and territorial political actions, since companies tend to be highly imbued with the local culture [36]. Given that SSBs are usually at the base of the pyramid and part of the livelihood of families in poverty [40], improving their competitiveness will increase the wealth of the territories in which they are found.

\section{Theoretical Structure}

Entrepreneurs of small businesses in developing countries have a robust motivation to support their families [41,42]. Their decisions are based on intuition, personal experience, and business sentiment [43]. They tend to be individualists, not participating in associations and limiting cooperation with their competitors. Owner-managers often have little formal education [44], which is also generally not oriented towards practical activity [42]. Given this lack of training, they have little market orientation (Jardon, Gutawski, Martos, Aguilar, \& Barajas, 2007), and have difficulty evaluating the costs of products [44]. The workers of these companies are usually not qualified, since SSBs have greater difficulties in finding qualified personnel $[42,45]$. They tend to operate at the frontier of the formal and informal sectors and are often in the latter [41], exposing their rivals to unfair competition. Consequently, SSBs have difficulties in financing and receiving public aid.

In particular, forest SSBs have restricted competitiveness, since the timber industry is a mature industry, with large economies of scale, benefiting large companies. Forest SSBs are generally dispersed throughout the territory, since they seek to be close to the raw material and to the client to reduce transportation costs [35]. Being very small, they have a high level of dependence on a dominant customer, which influences the decisions of the entrepreneur, such as in the choice of equipment, the duration of contracts, the type of agreement on rates, and others. [46]. Owner-managers of small businesses generally have a short-term planning horizon that is usually not well defined. Their marketing strategies are mainly based on opportunism and market opportunities. The main dimension of their performance focuses on production [39].

\subsection{SSBs: Sustainability}

Sustainability of SSBs requires sustainable competitive advantages. Sustainable competitive advantages are usually associated with the product or service and the market or clients [47]. According to Bridoux (1997:9) [48], "competitive advantage is a superior differentiation and/or lower costs by comparison with the marginal (breakeven) competitor in the product market." Forest SSBs are product-oriented [39]. Consequently, this study analyzed a set of aspects of the products or services and the type of client.

The promotion of products or services is fundamental for growth [49]. Promotion in SSBs is usually limited to personal relationships and flashy posters, according to the local culture, which is usually enough to attract new customers and to increase customer loyalty by being imbued as entrepreneurs of that culture. Consequently, the company grows.

The prices of products or services are essential for SSBs. These companies do not usually offer very elaborate products, so they tend to look for closeness to the client with prices that do not seem excessively overpriced, since their costs are also higher. For this reason, pricing policy is fundamental for SSBs to maintain their competitiveness. This greater competitiveness allows them to increase their sales [49].

Another important element in SSBs is their range of products or services, because, when competing in proximity, they are interested in offering a wide variety of products or services in such a way that the customers find most of the products they require, and therefore do not have to look for other competing companies [50], which increases the sales of the SSB. 
The SSBs use exclusive products or services as an element of competitiveness, especially when they are located in a territory where they have specific products that may not exist in other territories, as this feature allows them to differentiate themselves from competitors [51], attracting specific customers and increasing their sales.

The quality of products or services is especially important in SSBs, as some quality features must differentiate them with respect to large companies. In that sense, competitiveness depends on elements of quality in the product or service that differentiate them [52]. The quality in SSBs is usually restricted because of limited technology, but presents characteristics associated with local know-how [36]. Therefore, higher product quality increases the sales.

Finally, the type of customer is fundamental for SSBs, because such businesses attend differently to the usual customer and to the sporadic customer. In the first case, the loyalty that they offer with good treatment, generating greater trust, means that many of the competitive disadvantages of small businesses with respect to large companies disappear [49].

In consequence, competitive advantages result in a better performance of the company [53].

\subsection{Leadership in SSBS}

Brown \& Treviño (2006) [6] have detected three characteristics common to most theories about leadership, namely concern for others, integrity, and the organization of tasks (role modeling). Since in small companies, the training of managerial entrepreneurs is usually scarce, we will assume that these three characteristics can be adapted to the specific situation of these companies.

This paper is focused on analyzing leadership in SSBs. The concept of entrepreneurial leadership is of particular interest in SSBs, since the owner entrepreneur is usually the leader and manager of the company. Renko, El Tarabishy, Carsrud, and Brännback (2015) [54] suggest that entrepreneurial leadership involves influencing and directing the performance of group members towards the achievement of the organization's objectives, which entails identifying and exploiting business opportunities. Leitch and Volery, (2017) [55] suggest that entrepreneurial leadership is a new concept that combines the characteristics of leadership with the characteristics of entrepreneurship. In particular, entrepreneurial leadership should combine the characteristics of authentic leadership, charismatic leadership, and transformational leadership.

Given that SSBs tend to be in an initial stage within the business model and therefore do not usually have a very professional organizational structure, the concept of leadership will focus essentially on the leader as an example that inspires the rest of the company and as a motivator of work within the company.

Owners who manage small businesses usually show a hierarchical structure where they hardly share decisions. For this reason, an important characteristic of leaders is their ability to delegate, that is, teaching their subordinates to make decisions and taking the associated risks.

Therefore, this work considers the features of integrity, the ability to motivate, and the ability to delegate in the characterization of leadership.

From the intellectual-capital-based view, the leadership of an SSB must be a source of competitive advantage, that is, it must generate value for the company, be rare and difficult to imitate, and also be sustainable over time [56].

The generation of value by the leadership of the entrepreneur has been studied previously from multiple aspects $[7,8,54,57,58]$. The arguments used by these authors are valid in small businesses, since they relate to the strategic ability of the leader to manage and organize company resources [8]. When these resources are better organized, the probability of generating more value for the company increases.

Like all resources of human capital, leadership also has the characteristics of being rare and difficult to imitate, since the way to exercise it is very conditioned by the specific characteristics of the entrepreneur, and, possibly, elements that are valid in one company are more difficult to implement in another, especially when it comes to small businesses. 
The characteristics of sustainability will be linked to the capacity of the leader to adapt, since the way of managing the company must be adapted to the specific circumstances of growth and to the variations in the environment in which it develops.

Consequently,

H1: Leadership generates sustainable competitive advantages in SSBs.

\subsection{Organizational Culture}

The existence of forests conditions the local culture in a territory; its inhabitants will have used the wood and other forest products as construction and production material. This use creates a know-how that differentiates them from other territories, since it is connected with the type of wood and local habits. Consequently, a specific culture related to the product has been created.

"Organizational culture typically is defined as a complex set of values, beliefs, assumptions, and symbols that define the way in which a firm conducts its business" ([59], p. 657). Culture tends to be multi-faceted. This paper analyzed four important aspects for the development of competitiveness in SSBs: local values, organizational socialization, trust, and environmental concern.

The organizational culture in SSBs supports the local culture in the SSBs, as the cultural values of a territory condition the behavior of the inhabitants of that territory [60], including the entrepreneurs and workers of the SSBs, who are usually local.

Among the cultural aspects that condition competitive advantages of SSBs is organizational socialization, i.e., the collection of practices and values that facilitate the diffusion of knowledge among the workers. These practices are fundamental to enable the entry of new workers, to increase knowledge and routines within the company, to the future progress of the company, and to retain the knowledge learned. Adaptation entails developing and learning new routines. The efficacy of this learning requires unlearning of old and already embedded routines [61].

Trust is based on the attitude towards a collaboration of people. It is a concept that has been extensively studied and is extremely important in understanding economic relationships $[60,62]$. This study is interested in internal trust, i.e., trust among the workers of an organization and trust within the organization [63].

The environmental culture denotes the culture of protection for the environment, and includes the interest in using natural resources sustainably. This cultural issue is essential in the wood industry, since wood is a natural resource that requires sustainable use to keep its competitiveness.

Local culture facilitates the creation of specific products, customer services, and combinations of products and services, which differentiate the company from others. In addition, the common culture of workers and managers facilitates the work environment, i.e., the prevailing workplace atmosphere as felt by workers. The trust reduces transaction costs in the company [64]. These arguments are valid in SSBs.

Environmental concern is the basis of corporate social responsibility (CSR) as a source of sustainable competitiveness, especially in the forestry industry [65]. Previous studies have considered two complementary aspects of the environmental concern effect: one positive and one negative. On one hand, environmental activities can be an effective mechanism to build a vigorous enterprise-customer relationship and establish a potential distinction factor on competence. On the other hand, when a company is forced to fight for survival, it may explore such cost-cutting activities as environmentally harmful behaviors [66]. Empirical research has suggested that companies that offer environmentally-friendly products can attract more customers [67], and they can obtain preferential treatment from the government for being good corporate citizens [68].

These arguments suggest that:

H2: Culture in SSBs increases sustainable competitive advantages. 


\subsection{Culture, Leadership, and Sustainability}

The relationship between leadership and organizational culture has been supported by two somewhat contradictory trends [28]. The functionalist current suggests that leaders are those that generate cultural change, either through visible actions or through the symbolic role that they play [29]. The anthropological current, however, suggests that leaders are part of the organizational culture in which they move and, consequently, culture conditions leadership [30]. The functionalist current tends to be more common [31,32], but, in the case of small subsistence enterprises, extremely associated with the territory, this effect can change.

Subsistence small businesses are created as a means of support for the entrepreneur and their family, although entrepreneurs usually seek some opportunities from their environment. Consequently, entrepreneurs find opportunities within their local culture, since they have limited training. The local culture conditions the creation of the company and a large part of its initial actions. The organizational culture of the company is imbued with the culture of the territory. Local and organizational culture will condition the entrepreneur's actions and, consequently, his way of exercising leadership. In consequence,

H3: Organizational culture improves entrepreneurial leadership in the SSBs.

Cultural issues have been studied as a source of sustainable competitive advantage $[59,69]$, but SSBs present little strategic orientation [42], and the arguments of other companies are possibly not totally valid.

First, local culture reduces transaction costs, but to translate this reduction of cost into value for clients, it is necessary to have an efficient organizational system [70] and good leadership, which are usually not present in SSBs [71]. This effect is therefore limited. In addition, environmental culture increases the reputation of companies, but the utility of reputation as a sustainable competitive advantage requires an organizational system and leadership, especially in SSBs. Consequently,

H4: Cultures in SSBs need to be mediated by leadership to increase sustainable competitive advantages.

\section{Material and Methods}

\subsection{Data}

The province of Misiones bases its production [72] on forest and agro-industrial goods, which are mostly destined to the rest of the country and also to the external market. Misiones is a wooded region, with subtropical forests and varied species. Timber is one of the most important resources of the province, especially because of the fertile land and excellent climate that facilitate rapid tree growth, at a ratio of 2:1 with respect to the rest of the country.

The last census of the Argentine Federation of the Wood Industry and Related Industries (FAIMA) in 2010 showed that there were 971 operating industries registered in Misiones; 660 of them were sawmills, 140 furniture factories, and the rest joineries and other manufacturers. The majority were concentrated in the center and in the north east and west. Of these companies, 95\% were SMEs, in general of family origin, with a greater lack of training in management or use of existing resources. Their activity was usually oriented to the internal market.

The sample was selected by sampling companies proportional to their concentration in the territory, with an error of $5 \%$. The researchers visited each of the selected companies to conduct the survey, and realized an interview to reduce the response biases. The response rate was $78.5 \%$, verifying that it was adjusted to the population. Finally, 212 surveys were performed, and the error rate increased to $5.9 \%$. The results of the survey were tested with interviews to SSBs of Paraguay and Argentina three years after. 


\subsection{Measures}

The questionnaire followed the outline described previously [43], based on the scales found in the literature [8].

This paper measured leadership with a list of questions about inspiration and delegation; organizational culture was measured using four items, similar to Gu et al. (2014) [73], with a range of questions about local culture, organizational socialization, internal trust, and environment culture. To evaluate the questions, the questionnaire used a Likert scale of 1 (totally disagree) to 5 (totally agree), according to the degree of agreement with the statement (see Table 1). Competitive advantages were measured asking by about the competitive position for the company related to competitors, using a scale ranging from 1 (not important) to 5 (very important).

We used company size, measured by employment, as the control variable [74].

\subsection{Econometric Methods}

The model analyzed linear relationships between structural variables. The most popular technique used to focus on this problem is based on covariance analysis [75], but this method requires hard assumptions, especially the conjoint normal behavior of the variables used, which is difficult as the variables were measured on a Likert scale. Consequently, the research used an alternative approach, more flexible and less constrained by these assumptions, namely the partial least squares (PLS) technique. This method realized a direct estimation of structural relationships using least squares techniques [76], thereby minimizing the variance of all dependent variables. This approach avoids problems such as the identification of parameters in the covariance model, and does not need an assumption of normality of the variables [76].

Table 1. Items to measure variables.

\begin{tabular}{|c|c|c|c|}
\hline \multicolumn{4}{|c|}{ Culture } \\
\hline \multicolumn{2}{|c|}{ Local culture-CU1 } & $\begin{array}{l}\text { There are values, attitudes, and behaviors shared by all staff that facilitate } \\
\text { the work climate }\end{array}$ & [77] \\
\hline \multirow{2}{*}{\multicolumn{2}{|c|}{$\begin{array}{l}\text { Environmental concern-CU2 } \\
\text { Organizational socialization-CU3 }\end{array}$}} & There is a continuing concern to avoid pollution and improve the environment & [65] \\
\hline & & There is a culture of transmitting experiences to new workers & [78] \\
\hline \multicolumn{2}{|c|}{ Trust-CU4 } & There is a high degree of trust between the people of the company leadership & [64] \\
\hline \multicolumn{2}{|c|}{ HC1-Inspiration } & $\begin{array}{l}\text { The entrepreneur inspires employees to solve complex problems, which aims to } \\
\text { obtain outstanding results. }\end{array}$ & [79] \\
\hline \multicolumn{2}{|c|}{ HC2-Delegation } & Managers delegate authority and decision-making & [80] \\
\hline \multicolumn{2}{|c|}{ HC3-Motivation } & $\begin{array}{l}\text { The entrepreneur is an example of a successful entrepreneur and professional } \\
\text { competitive advantages }\end{array}$ & [81] \\
\hline \multicolumn{2}{|c|}{ VSF1 } & The promotion of products/services & [49] \\
\hline \multicolumn{2}{|c|}{ VSF2 } & The price we have the products/services & [49] \\
\hline \multicolumn{2}{|c|}{ VSF3 } & The range of the portfolio of products/services & [50] \\
\hline \multicolumn{2}{|c|}{ VSF4 } & The exclusivity of products/service & [51] \\
\hline \multicolumn{2}{|c|}{ VSF5 } & The quality of products/services & [52] \\
\hline \multicolumn{2}{|c|}{ VSF6 } & Customer service & [49] \\
\hline \multicolumn{4}{|c|}{ Performance } \\
\hline \multicolumn{2}{|c|}{ Growth (GP) } & Turnover & [82] \\
\hline \multirow{4}{*}{ Financial } & PF1 & Cash flow & [83] \\
\hline & PF2 & Net profit & [50] \\
\hline & PF3 & Profitability & [50] \\
\hline & PF4 & Solvency & [50] \\
\hline
\end{tabular}

This technique uses the average variance extracted (AVE), Dillon-Goldstein's rho (DG), and Cronbach's alpha (CA) as criteria to validate. The AVE measures the variance captured by a latent construct. This amount should be greater than 0.5 to explain more indicators than the error. Dillon-Goldstein's rho analyzes the homogeneity of the blocks; these are considered homogenous if this index is larger than 0.7. The CA is based on the analysis of average correlations among the items referred to a single aspect, from a single administration of the questionnaire. The construct is right if CA is greater than $0.6[76,84]$. 
The relationship between culture and leadership is complex, and it is not clear if it has a feedback effect or, on the contrary, if one is the cause of another. One of the objectives of this paper was to determine the process of causation between culture and leadership in SSBs. Therefore, to determine this process, three alternative models are proposed: the first presupposes the simultaneous impacts of culture and leadership on competitive advantages; the second analyzes culture as a mediator between leadership and competitive advantages; the third studies leadership as a mediator between culture and competitive advantages.

Consequently, the process to analyze the hypotheses presented consisted of two phases. In a first phase, the model that best explains the behavior of the variables was selected, while in the second phase, the hypotheses were tested based on the selected model.

Given that neither of these models is contained in the other and that the estimates were carried out using least squares methods that are not based on statistical distributions, the research used the GoF criterion [85] to select the model, as this criterion conjointly measures the degree of explanation of each latent variable from the observed variables and the causality relationships between the latent variables.

To validate the model, the research used bootstrap methodology [86]. The calculation was done in R 3.4, based on the PLS-PM package [87].

\section{Results}

A first analysis was performed to confirm the variables included in the models. The quality of the products and services was deleted, because these businesses usually do not compete in terms of quality. The remaining variables and correlations are included in Appendix A.

The results comparing the adjustment in the three models indicate that the most valued one is model 3, with a GoF of 0.31. Therefore, we used this model in the remaining calculations (Figure 1).

Cronbach's Alpha and DG-pho indicated that the variables met the requirements of unidimensionality that were required (see Table 2).

Estimation via the bootstrap method indicated that all factorial loadings could be considered positive, being in agreement with the definition criteria in the measurement of variables (see Table 2). Bootstrap testing confirmed this assumption.

The reliability of the variables could also be accepted because the AVE was greater than 0.5 (see Table 2), and the cross-loadings verified the criteria of indirect reliability, being greater in the main diagonal (see Table 2).

The estimation of the model suggests that culture has a positive and significant impact on leadership and competitive advantages, which shows the validity of Hypothesis 2 and Hypothesis 3. Complementarily, leadership presents a significant and positive impact on competitive advantages, suggesting that Hypothesis 1 is valid (see Table 3 ). 


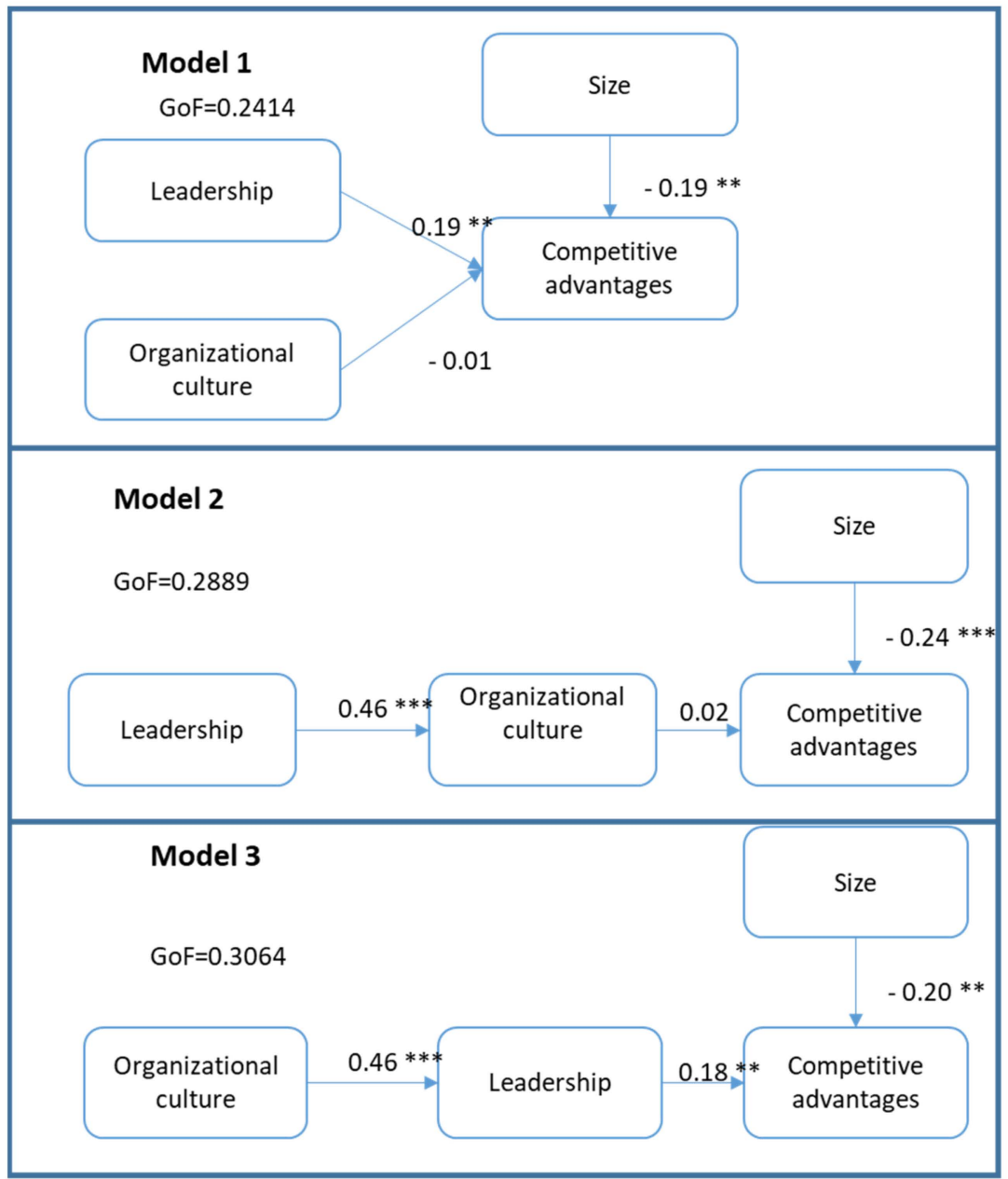

* Significance at 0.1

** Significance at 0.05

*** Significance at 0.01

Figure 1. Models estimation.

Table 2. Reliability and unidimensionality.

\begin{tabular}{|c|c|c|c|c|c|}
\hline & & Culture & Leadership & Size & Competitive Advantages \\
\hline \multicolumn{6}{|l|}{ Culture } \\
\hline & CU1 & 0.4948 & 0.12655 & -0.3617 & 0.0757 \\
\hline C.alpha $=0.701$ & CU2 & 0.55749 & 0.13727 & -0.185 & 0.0763 \\
\hline DG.rho $=0.817$ & CU3 & 0.85557 & 0.41917 & -0.388 & 0.0361 \\
\hline $\mathrm{AVE}=0.5$ & CU4 & 0.83317 & 0.4305 & -0.09 & 0.0979 \\
\hline \multicolumn{6}{|l|}{ Leadership } \\
\hline C.alpha $=0.645$ & hc1 & 0.34353 & 0.84551 & -0.372 & 0.2621 \\
\hline DG.rho $=0.809$ & hc2 & 0.33653 & 0.72053 & -0.1959 & 0.1819 \\
\hline $\begin{array}{c}\mathrm{AVE}=0.586 \\
\text { size }\end{array}$ & hc3 & 0.39189 & 0.72436 & -0.0987 & 0.0789 \\
\hline 3 & PG2 & -0.31823 & -0.30431 & 1 & -0.2568 \\
\hline \multicolumn{6}{|c|}{ Competitive advantages } \\
\hline & VSF1 & 0.07664 & -0.00234 & -0.1769 & 0.8525 \\
\hline C.alpha $=0.905$ & VSF2 & 0.00543 & 0.15933 & -0.1869 & 0.8312 \\
\hline DG.rho $=0.93$ & VSF3 & 0.11987 & 0.20764 & -0.1931 & 0.8586 \\
\hline \multirow[t]{2}{*}{$\mathrm{AVE}=0.718$} & VSF4 & 0.12192 & 0.26511 & -0.2413 & 0.8759 \\
\hline & VSF6 & 0.04354 & 0.22966 & -0.2499 & 0.8178 \\
\hline
\end{tabular}


Table 3. Total effects and bootstrap intervals.

\begin{tabular}{cccccc}
\hline & Original & Mean.Boot & Std.Error & Perc.025 & Perc.975 \\
\hline Culture on competitive advantages & 0.46 & 0.47 & 0.05 & 0.37 & 0.56 \\
Culture on leadership & 0.08 & 0.09 & 0.03 & 0.04 & 0.14 \\
Leadership on competitive advantages & 0.17 & 0.19 & 0.05 & 0.08 & 0.29 \\
Size on competitive advantages & -0.20 & -0.20 & 0.07 & -0.34 & -0.05 \\
\hline
\end{tabular}

\section{Discussion}

The paper analyzed the interaction between culture and leadership in order to increase the sustainability of SSBs.

The results indicate that culture has an effect on competitive advantages, but this effect is mediated through leadership. The importance of culture has been studied previously [59]. In particular, Hategan et al. (2019) [71] analyzed the effect of culture on sustainability in family businesses. This result shows how one aspect of structural capital affects financial performance, coinciding with $\mathrm{Xu}$ et al. (2018) [15].

The second was to analyze what theory best explains the behavior of SSBs. The results suggest that, in SSBS, the anthropological theory is verified [30], i.e., that the culture conditions the leadership in the company, and not that the leadership conditions the culture [31,32].

Leadership is what serves to obtain competitive advantages, and, consequently, the culture needs to be reflected in the specific efforts of a leader who makes the company more competitive, according to Sarros et al. (2011) [28].

In addition, leadership affects competitive advantages, which is in accordance with the classical tradition of strategic leadership, although, in this case, it was shown that leadership is a source of competitive advantage, as it forms part of the human capital of the company [7].

Culture does not directly affect competitive advantage, necessitating intermediate elements that channel this effect. This limitation is specific to SSBs, which is in contrast to previous studies stating that culture is a generator of competitive advantage $[20,21,88]$. In general, a culture that does not rely on an organizational system does not manifest itself in the competitiveness of the company.

However, organizational culture has an indirect effect and can therefore be considered a source of competitive advantage, coinciding with previous research [22]. However, the arguments used in these papers do not seem to be directly valid in the case of the SSBs.

\section{Conclusions}

The relationship between leadership and organizational culture has been widely studied, and is of great importance in management literature. Although previous studies have opted for a functionalist foundation, that is to say, the premise that leadership conditions culture, in this work, we showed that culture conditions leadership, so it seems more logical to make use of an anthropological vision. This is a feature that differentiates these small businesses from the companies studied in the management literature.

This paper also shows that leadership is a source of competitive advantage, which is in agreement with previous studies on the meaning of strategic leadership, of which the arguments are valid for SSBs.

On the other hand, it shows that culture does not have a direct effect on competitive advantage, in contrast to previous studies, although an indirect effect was measured through leadership. Therefore, in agreement with the findings of previous studies, culture is a source of competitive advantage, but culture does not generate competitiveness directly; an organizational culture needs to act through entrepreneurial leadership. 


\subsection{Managerial and Political Implications}

The results of the article show a series of aspects that can help to improve the functioning and management of SSBs.

First, it shows that culture plays an important part in modeling leadership in SSBs. Therefore, political actions should be aimed at fostering a business culture that generates growth. Bruhn et al. (2010) [26] suggests that this culture, associated with managerial capital, should be taught to subsistence entrepreneurs to become transforming entrepreneurs.

Second, leadership is necessary to generate competitiveness in SSBs, so the managers of these companies should be oriented towards a strategic leadership that helps them to improve their competitiveness. In that sense, training policies should be followed, especially in organizational and strategic management [89]. Leadership learning is especially needed in the case of the owner-manager to determine the organizational structure and the strategic lines of the company [45]. The training of leaders requires the joint action of social agents. For example, business consultants should encourage this leadership [26], training directly in business schools or through coaching [90]. In the same way, the political actions and, especially, the formation of business schools in those areas should be oriented toward the formation of strategic leaders, resulting in potential growth of SSBs. Training institutions should promote entrepreneurial competencies to professionalize the managers of SSBs [91].

Organizational culture does not directly affect competitive advantage, but, rather, the mediation of leadership. Thus, managers must prioritize their way of exercising leadership in the face of more secondary aspects such as work climate or the organization of teams. In the same way, consultants and social actors should help entrepreneurs to exercise a strategic leadership, rather than acting on cultural aspects of the company itself [26].

\subsection{Limitations and Future Research}

We used data from a specific region and sector, and, therefore, any generalizations from this study must be made with caution. This paper analyzes the behavior of forest SSBs in a particular case, which may limit its scope, and it is therefore advisable to complement its conclusions with similar studies.

The measures of the variables were all subjective, which could limit the validity and scope of the results, and the calculations were made on cross-sectional data, although in subsequent interviews, the results were checked.

The paper has definite implications for future research, both in the form of follow-up studies of the subject material and in the application of the analysis to other locations. This research shows the importance of leadership in the competitiveness and growth of small businesses.

Author Contributions: Conceptualization, C.M.J. and X.M.-C.; methodology, C.M.J.; software, C.M.J.; validation, X.M.-C; formal analysis, C.M.J. and X.M.-C.; investigation, C.M.J. and X.M.-C.; resources, C.M.J. and X.M.-C.; data curation, C.M.J.; writing-original draft preparation, C.M.J.; writing-review and editing, X.M.-C.; visualization, C.M.J. and X.M.-C.; supervision, C.M.J. and X.M.-C.; project administration, C.M.J.

Acknowledgments: We thanks the collaboration of the Nilda Tañski, for your help to get information about the data and the context.

Conflicts of Interest: The authors declare no conflict of interest. 


\section{Appendix A}

Table A1. Descriptive statistics.

\begin{tabular}{lccccccccccccccc}
\hline & \multicolumn{11}{c}{ Correlations } \\
\hline & mean & sd & CU1 & CU2 & CU3 & CU4 & hc1 & hc2 & hc3 & PG2 & VSF1 & VSF2 & VSF3 & VSF4 & VSF6 \\
\hline CU1 & 3.52 & 0.85 & 1.00 & 0.51 & 0.30 & 0.23 & 0.08 & 0.18 & 0.02 & -0.36 & 0.16 & 0.08 & 0.04 & 0.06 & 0.04 \\
CU2 & 3.22 & 0.96 & 0.51 & 1.00 & 0.38 & 0.27 & 0.04 & 0.07 & 0.23 & -0.19 & 0.07 & -0.02 & 0.11 & 0.12 & 0.03 \\
CU3 & 3.66 & 0.96 & 0.30 & 0.38 & 1.00 & 0.52 & 0.32 & 0.36 & 0.28 & -0.39 & 0.00 & -0.07 & 0.12 & 0.08 & -0.01 \\
CU4 & 3.43 & 0.85 & 0.23 & 0.27 & 0.52 & 1.00 & 0.34 & 0.24 & 0.42 & -0.09 & 0.09 & 0.06 & 0.08 & 0.11 & 0.08 \\
hc1 & 3.24 & 0.95 & 0.08 & 0.04 & 0.32 & 0.34 & 1.00 & 0.40 & 0.47 & -0.37 & 0.03 & 0.19 & 0.16 & 0.28 & 0.31 \\
hc2 & 3.34 & 0.83 & 0.18 & 0.07 & 0.36 & 0.24 & 0.40 & 1.00 & 0.26 & -0.20 & 0.04 & 0.16 & 0.24 & 0.16 & 0.11 \\
hc3 & 3.50 & 1.00 & 0.02 & 0.23 & 0.28 & 0.42 & 0.47 & 0.26 & 1.00 & -0.10 & -0.09 & 0.00 & 0.07 & 0.16 & 0.08 \\
PG2 & 2.64 & 0.87 & -0.36 & -0.19 & -0.39 & -0.09 & -0.37 & -0.20 & -0.10 & 1.00 & -0.18 & -0.19 & -0.19 & -0.24 & -0.25 \\
VSF1 & 3.75 & 1.20 & 0.16 & 0.07 & 0.00 & 0.09 & 0.03 & 0.04 & -0.09 & -0.18 & 1.00 & 0.74 & 0.71 & 0.76 & 0.58 \\
VSF2 & 3.75 & 1.34 & 0.08 & -0.02 & -0.07 & 0.06 & 0.19 & 0.16 & 0.00 & -0.19 & 0.74 & 1.00 & 0.82 & 0.57 & 0.52 \\
VSF3 & 3.84 & 1.22 & 0.04 & 0.11 & 0.12 & 0.08 & 0.16 & 0.24 & 0.07 & -0.19 & 0.71 & 0.82 & 1.00 & 0.63 & 0.53 \\
VSF4 & 3.42 & 1.25 & 0.06 & 0.12 & 0.08 & 0.11 & 0.28 & 0.16 & 0.16 & -0.24 & 0.76 & 0.57 & 0.63 & 1.00 & 0.68 \\
VSF6 & 3.53 & 1.22 & 0.04 & 0.03 & -0.01 & 0.08 & 0.31 & 0.11 & 0.08 & -0.25 & 0.58 & 0.52 & 0.53 & 0.68 & 1.00 \\
\hline
\end{tabular}

Table A2. Questionnaire.

\begin{tabular}{|c|c|c|}
\hline $\begin{array}{l}\text { Please, Indicate the Degree of Agreement with the Following } \\
\text { Statement about of Your Company }\end{array}$ & Totally Disagree & Totally Agree \\
\hline $\begin{array}{l}\text { There are values, attitudes and behaviors shared by all the staff } \\
\text { that facilitate the work climate } \\
\text { There is a continuing concern to avoid pollution and improve } \\
\text { the environment } \\
\text { There is a culture of transmitting experiences to new workers } \\
\text { There is a high degree of trust between the people of the company } \\
\text { The entrepreneur inspires employees to solve complex problems, } \\
\text { which aims to obtain outstanding results. } \\
\text { Managers delegate authority and decision-making } \\
\text { The entrepreneur is an example of a successful entrepreneur } \\
\text { and professional }\end{array}$ & & \\
\hline $\begin{array}{l}\text { Please, indicates if your company has the following items are } \\
\text { competitive advantages versus your competitors }\end{array}$ & It is not competitive advantage & It is a competitive advantage \\
\hline $\begin{array}{l}\text { Please indicate how the results of your company have evolved } \\
\text { in the last two years }\end{array}$ & Have decreased very much & Have increased very much \\
\hline $\begin{array}{l}\text { The turnover } \\
\text { The cash flow } \\
\text { Net profit } \\
\text { Profitability } \\
\text { Solvency }\end{array}$ & & \\
\hline What are your size? & $\begin{array}{l}\text { less to } 5 \\
5 \text { to } 10 \\
10 \text { to } 25 \\
25 \text { to } 50 \\
\text { more of } 50\end{array}$ & \\
\hline
\end{tabular}

\section{References}

1. Azmat, F.; Samaratunge, R. Responsible Entrepreneurship in Developing Countries: Understanding the Realities and Complexities. J. Bus. Ethics 2009, 90, 437-452. [CrossRef]

2. Eijdenberg, E.L.; Paas, L.J.; Masurel, E. Entrepreneurial motivation and small business growth in Rwanda. J. Entrep. Emerg. Econ. 2015, 7, 212-240. [CrossRef]

3. Eijdenberg, E.L.; Paas, L.J.; Masurel, E. Decision-making and small business growth in Burundi. J. Entrep. Emerg. Econ. 2017, 9, 35-64. [CrossRef] 
4. Wiklund, J.; Patzelt, H.; Shepherd, D.A. Building an integrative model of small business growth. Small Bus. Econ. 2009, 32, 351-374. [CrossRef]

5. Wang, Y. Impacts of leadership style on the development of small business: Lessons from a Chinese family-controlled firm. Int. J. Manag. Pract. 2005, 1, 215-232. [CrossRef]

6. Brown, M.E.; Treviño, L.K. Ethical leadership: A review and future directions. Leadersh. Q. 2006, 17, 595-616. [CrossRef]

7. Bryant, S.E. The Role of Transformational and Transactional Leadership in Creating, Sharing and Exploiting Organizational Knowledge. J. Leadersh. Organ. Stud. 2003, 9, 32-44. [CrossRef]

8. Hitt, M.A.; Duane, R. The Essence of Strategic Leadership: Managing Human and Social Capital. J. Leadersh. Organ. Stud. 2002, 9, 3-14. [CrossRef]

9. Jing, F.F. Leadership paradigms and performance in small service firms. J. Manag. Organ. 2018, 24, 339-358. [CrossRef]

10. Dionne, S.D.; Gupta, A.; Sotak, K.L.; Shirreffs, K.A.; Serban, A.; Hao, C.; Yammarino, F.J. A 25-year perspective on levels of analysis in leadership research. Leadersh. Q. 2014, 25, 6-35. [CrossRef]

11. Reed, K.K.; Lubatkin, M.; Srinivasan, N. Proposing and Testing an Intellectual Capital-Based View of the Firm. J. Manag. Stud. 2006, 43, 867-893. [CrossRef]

12. Yi, C.-G. Intellectual capital indicators for the Korean public research institute. Int. J. Intell. Enterp. 2012, 1, 199-214. [CrossRef]

13. Stewart, T. Intellectual Capital: The New Wealth of Organizations Intellectual Capital; Doubleday Dell Publishing Group: New York, NY, USA, 1997.

14. Brooking, A. Intellectual Capital; Internatinal Thompson Business Press: London, UK, 1996.

15. Xu, J.; Wang, B.; Xu, J.; Wang, B. Intellectual Capital, Financial Performance and Companies' Sustainable Growth: Evidence from the Korean Manufacturing Industry. Sustainability 2018, 10, 4651. [CrossRef]

16. Battagello, F.M.; Cricelli, L.; Grimaldi, M.; Battagello, F.M.; Cricelli, L.; Grimaldi, M. Prioritization of Strategic Intangible Assets in Make/Buy Decisions. Sustainability 2019, 11, 1267. [CrossRef]

17. Lee, J.; Kim, S.; Lee, J.; Moon, S. Enhancing Employee Creativity for A Sustainable Competitive Advantage through Perceived Human Resource Management Practices and Trust in Management. Sustainability 2019, 11, 2305. [CrossRef]

18. Li, Y.; Song, Y.; Wang, J.; Li, C. Intellectual Capital, Knowledge Sharing, and Innovation Performance: Evidence from the Chinese Construction Industry. Sustainability 2019, 11, 2713. [CrossRef]

19. Ali, H.S.H.; Said, R.M.; Abdullah, A.; Daud, Z.M. The impact of organizational culture on corporate financial performance: A review. Int. J. Econ. Commer. Manag. 2017, 6, 8.

20. Sadri, G.; Lees, B. Developing corporate culture as a competitive advantage. J. Manag. Dev. 2001, 20, 853-859. [CrossRef]

21. Gordon, G.G.; DiTomaso, N. Predicting corporate performance from organizational culture. J. Manag. Stud. 1992, 29, 783-798. [CrossRef]

22. Zheng, W.; Yang, B.; McLean, G.N. Linking organizational culture, structure, strategy, and organizational effectiveness: Mediating role of knowledge management. J. Bus. Res. 2010, 63, 763-771. [CrossRef]

23. Yesil, S.; Kaya, A. The Effect of Organizational Culture on Firm Financial Performance: Evidence from a Developing Country. Procedia Soc. Behav. Sci. 2013, 81, 428-437. [CrossRef]

24. Kumar, N. Organizational culture as a root of performance improvement. Contemp. Manag. Res. $2008,4,1$. [CrossRef]

25. Lee, S.K.J.; Yu, K. Corporate culture and organizational performance. J. Manag. Psychol. 2004, 19, 340-359.

26. Bruhn, B.M.; Karlan, D.; Schoar, A. What Capital is Missing in Developing Countries? Am. Econ. Rev. Pap. Proc. 2010, 100, 629-633. [CrossRef]

27. Kotter, J. Cultures and coalitions. In Rethinking the Future: Rethinking Business, Principles, Competition, Control and Complexity, Leadership, Markets and the World; Gibson, R., Ed.; Nicholas Brealey: London, UK, 1998.

28. Sarros, J.C.; Cooper, B.K.; Santora, J.C. Leadership vision, organizational culture, and support for innovation in not-for-profit and for-profit organizations. Leadersh. Organ. Dev. J. 2011, 32, 291-309. [CrossRef]

29. Meindl, J.R.; Ehrlich, S.B.; Dukerich, J.M. The Romance of Leadership. Adm. Sci. Q. 1985, 30, 78. [CrossRef]

30. Meek, V.L. Organizational Culture: Origins and Weaknesses. Organ. Stud. 1988, 9, 453-473. [CrossRef]

31. Schein, E.H. Organizational Culture and Leadership; Jossey-Bass Publishers: San Francisco, CA, USA, 1992. 
32. Denison, D.R.; Mishra, A.K. Toward a Theory of Organizational Culture and Effectiveness. Organ. Sci. 1995, 6, 204-223. [CrossRef]

33. Vallejo-Martos, M.C. The organizational culture of family firms as a key factor of competitiveness. J. Bus. Econ. Manag. 2011, 12, 451-481. [CrossRef]

34. Yiing, L.H.; Ahmad, K.Z.B. The moderating effects of organizational culture on the relationships between leadership behaviour and organizational commitment and between organizational commitment and job satisfaction and performance. Leadersh. Organ. Dev. J. 2009, 30, 53-86. [CrossRef]

35. Peltoniemi, M. Mechanisms of capability evolution in the Finnish forest industry cluster. J. For. Econ. 2013, 19, 190-205. [CrossRef]

36. Bliss, J.C.; Kelly, E.C. Comparative Advantages of Small-Scale Forestry Among Emerging Forest Tenures. Small Scale For. 2008, 7, 95-104. [CrossRef]

37. Etongo, D.; Djenontin, I.N.S.; Kanninen, M.; Glover, E.K. Assessing use-values and relative importance of trees for livelihood values and their potentials for environmental protection in Southern Burkina Faso. Environ. Dev. Sustain. 2017, 19, 1141-1166. [CrossRef]

38. Camacho, L.D.; Combalicer, M.S.; Yeo-Chang, Y.; Combalicer, E.A.; Carandang, A.P.; Camacho, S.C.; Rebugio, L.L. Traditional forest conservation knowledge/technologies in the Cordillera, Northern Philippines. For. Policy Econ. 2012, 22, 3-8. [CrossRef]

39. Drolet, S.; LeBel, L. Forest harvesting entrepreneurs, perception of their business status and its influence on performance evaluation. For. Policy Econ. 2010, 12, 287-298. [CrossRef]

40. Christensen, L.J.; Parsons, H.; Fairbourne, J. Building Entrepreneurship in Subsistence Markets: Microfranchising as an Employment Incubator. J. Bus. Res. 2010, 63, 595-601. [CrossRef]

41. Schoar, A. The Divide between Subsistence and Transformational Entrepreneurship. In Innovation Policy and the Economy; Lerner, J., Stern, S., Eds.; University of Chicago Press: Chicago, IL, USA, 2010; pp. 57-81.

42. Adam, Y.O.; Pettenella, D. The Contribution of Small-Scale Forestry-Based Enterprises to the Rural Economy in the Developing World: The Case of the Informal Carpentry Sector, Sudan. Small Scale For. 2013, 12, 461-474. [CrossRef]

43. Jardon, C.M.; Martos, M.S. Intellectual capital as competitive advantage in emerging clusters in Latin America. J. Intellect. Cap. 2012, 13, 457-484. [CrossRef]

44. London, T.; Anupindi, R.; Sheth, S. Creating mutual value: Lessons learned from ventures serving base of the pyramid producers. J. Bus. Res. 2010, 63, 582-594. [CrossRef]

45. Jardon, C.M.; Gutawski, S.; Martos, S.; Aguilar, C.; Barajas, A. Visión Estratégica de la Cadena Empresarial de la Madera de Oberá, Misiones; Edunam-Editorial Universitaria de la Universidad Nacional de Misiones: Posadas, Argentina, 2007.

46. Mäkinen, P. Success factors for forest machine entrepreneurs. J. For. Eng. 1997, 8, 27-35.

47. Porter, M.E. Competitive Advantage; The Free Press: New York, NY, USA, 1985.

48. Bridoux, F. A Resource-Based Approach to Performance and Competition: An Overview of the Connections between Resources and Competition. Strateg. Manag. J. 1997, 18, 1-21.

49. O'Cass, A.; Sok, P. The role of intellectual resources, product innovation capability, reputational resources and marketing capability combinations in SME growth. Int. Small Bus. J. 2014, 32, 996-1018. [CrossRef]

50. Camisón-Zornoza, C. Shared, Competitive and Comparative Advantages: A Competence-Based View of the Competitiveness of Industrial Districts. Environ. Plan. 2004, 36, 2227-2256. [CrossRef]

51. Clapp, R.A. Creating Competitive Advantage: Forest Policy as Industrial Policy in Chile. Econ. Geogr. 1995, 71, 273. [CrossRef]

52. Naor, M.; Goldstein, S.M.; Linderman, K.W.; Schroeder, R.G. The Role of Culture as Driver of Quality Management and Performance: Infrastructure Versus Core Quality Practices*. Decis. Sci. 2008, 39, 671-702. [CrossRef]

53. Barney, J.; Wright, M.; Ketchen, D.J. The resource-based view of the firm: Ten years after 1991. J. Manag. 2001, 27, 625-641. [CrossRef]

54. Renko, M.; el Tarabishy, A.; Carsrud, A.L.; Brännback, M. Understanding and Measuring Entrepreneurial Leadership Style. J. Small Bus. Manag. 2015, 53, 54-74. [CrossRef]

55. Leitch, C.M.; Volery, T. Entrepreneurial leadership: Insights and directions. Int. Small Bus. J. 2017, 35, 147-156. [CrossRef]

56. Barney, J.B. Firm Resources and Sustained Competitive Advantage. J. Manag. 1991, 17, 99-120. [CrossRef] 
57. Ketelhohn, W. Strategic management practice in Latin America. J. Bus. Res. 2006, 59, 305-309. [CrossRef]

58. Hoon Song, J.; Kolb, J.A.; Hee Lee, U.; Kyoung Kim, H. Role of transformational leadership in effective organizational knowledge creation practices: Mediating effects of employees' work engagement. Hum. Resour. Dev. Q. 2012, 23, 65-101. [CrossRef]

59. Barney, J.B. Organizational Culture: Can It Be a Source of Sustained Competitive Advantage? Acad. Manag. Rev. 1986, 11, 656-665. [CrossRef]

60. Iyer, R.; Schoar, A. Are There Cultural Determinants of Entrepreneurship? In International Differences in Entrepreneurship; Lerner, J., Schoar, A., Eds.; University of Chicago Press: Chicago, IL, USA, 2010; pp. $209-240$.

61. Knight, G.A.; Cavusgil, S.T. Innovation, organizational capabilities, and the born-global firm. J. Int. Bus. Stud. 2004, 35, 124-141. [CrossRef]

62. Liao, T.-J. Cluster and performance in foreign firms: The role of resources, knowledge, and trust. Ind. Mark. Manag. 2010, 39, 161-169. [CrossRef]

63. Ismail, M.D. Learning orientation and trust in small and medium enterprise (SME) export competitive advantage. Asian Acad. Manag. J. 2013, 18, 153-179.

64. Bachmann, R.; Inkpen, A.C. Understanding Institutional-based Trust Building Processes in Inter-organizational Relationships. Organ. Stud. 2011, 32, 281-301. [CrossRef]

65. Li, N.; Toppinen, A. Corporate responsibility and sustainable competitive advantage in forest-based industry: Complementary or conflicting goals? For. Policy Econ. 2011, 13, 113-123. [CrossRef]

66. Tang, Z.; Tang, J. The Impact of Competitors-Firm Power Divergence on Chinese SMES' Environmental and Financial Performance. J. Bus. Ethics 2016, 136, 147-165. [CrossRef]

67. Jenkins, H. Small Business Champions for Corporate Social Responsibility. J. Bus. Ethics 2006, 67, $241-256$. [CrossRef]

68. Williamson, D.; Lynch-Wood, G.; Ramsay, J. Drivers of Environmental Behaviour in Manufacturing SMEs and the Implications for CSR. J. Bus. Ethics 2006, 67, 317-330. [CrossRef]

69. Büschgens, T.; Bausch, A.; Balkin, D.B. Organizational Culture and Innovation: A Meta-Analytic Review. J. Prod. Innov. Manag. 2013, 30, 763-781. [CrossRef]

70. Siguaw, J.A.; Simpson, P.M.; Enz, C.A. Conceptualizing Innovation Orientation: A Framework for Study and Integration of Innovation Research. J. Prod. Innov. Manag. 2006, 23, 556-574. [CrossRef]

71. Hategan, C.-D.; Curea-Pitorac, R.-I.; Hategan, V.-P.; Hategan, C.-D.; Curea-Pitorac, R.-I.; Hategan, V.-P. The Romanian Family Businesses Philosophy for Performance and Sustainability. Sustainability 2019, 11, 1715. [CrossRef]

72. Freaza, M.A. Economia de Misiones; Imprenta AR: Posadas, Argentina, 2000.

73. Gu, V.C.; Hoffman, J.J.; Cao, Q.; Schniederjans, M.J. The effects of organizational culture and environmental pressures on IT project performance: A moderation perspective. Int. J. Proj. Manag. 2014, 32, 1170-1181. [CrossRef]

74. Clarke, M.; Seng, D.; Whiting, R.H.; Bontis, N.; Keow, C.W.C.; Richardson, S. Intellectual capital and firm performance in Australia. J. Intellect. Cap. 2011, 12, 505-530. [CrossRef]

75. Hair, J.; Black, W.; Babin, B.; Anderson, R.; Tatham, R. Multivariate Data Analysis, 6th ed.; Pearson Prentice Hall: Upper Saddle River, NJ, USA, 2006.

76. Chin, W.W. The partial least squares approach for structural equation modeling. In Modern Methods for Business Research Methodology for Business and Management; Marcoulides, G.A., Ed.; Lawrence Erlbaum Associates Publishers: Mahwah, NJ, USA, 1998; pp. 295-336.

77. Alhojärvi, P. Forests and local cultures-Cultural sustainability of forestry: Basic analysis on the approach and disciplines. Radovi 2007, 42, 67-80.

78. Danneels, E. The dynamics of product innovation and firm competences. Strateg. Manag. J. 2002, 23, $1095-1121$. [CrossRef]

79. Dunne, T.C.; Aaron, J.R.; McDowell, W.C.; Urban, D.J.; Geho, P.R. The impact of leadership on small business innovativeness. J. Bus. Res. 2016, 69, 4876-4881. [CrossRef]

80. Mitchelmore, S.; Rowley, J. Entrepreneurial competencies: A literature review and development agenda. Int. J. Entrep. Behav. Res. 2010, 16, 92-111. [CrossRef]

81. Vidal, G.G.; Campdesuñer, R.P.; Rodríguez, A.S.; Vivar, R.M. Contingency theory to study leadership styles of small businesses owner-managers at Santo Domingo, Ecuador. Int. J. Eng. Bus. Manag. 2017, 9. [CrossRef] 
82. Kirkwood, J. To grow or not? Growing small service firms. J. Small Bus. Enterp. Dev. 2009, 16, 485-503. [CrossRef]

83. Chakravarthy, B.S. Measuring strategic performance. Strateg. Manag. J. 1986, 7, 437-458. [CrossRef]

84. Nunnally, J.; Bernstein, I. Psychometric Theory, 3rd ed.; McGraw-Hill Humanities/Social Sciences/Languages: New York, NY, USA, 1994.

85. Tenenhaus, M.; Amato, S.; Vinzi, V.E. A global Goodness-of-Fit index for PLS structural equation modelling. In Proceedings of the 42th SIS Scientific Meeting, Phoenix, AZ, USA, 3 February 2008.

86. Efron, B. Bootstrap Methods: Another Look at the Jackknife. Ann. Stat. 1979, 7, 1-26. [CrossRef]

87. Sanchez, G. PLS Path Modeling with R; Trowchez Editions: Berkeley, CA, USA, 2013.

88. Dadzie, C.A.; Winston, E.M.; Dadzie, K.Q. Organizational Culture, Competitive Strategy, and Performance in Ghana. J. Afr. Bus. 2012, 13, 172-182. [CrossRef]

89. Anand, J.; Brenes, E.; Karnani, A.; Rodriquez, A. Strategic responses to economic liberalization in emerging economies: Lessons from experience. J. Bus. Res. 2006, 59, 365-371. [CrossRef]

90. Vidal-Salazar, M.D.; Ferrón-Vílchez, V.; Cordón-Pozo, E. Coaching: An effective practice for business competitiveness. Compet. Rev. 2012, 22, 423-433.

91. Kantis, H.; Ishida, M.; Komori, M. Entrepreneurship in Emerging Economies: The Creation and Development of New Firms in Latin America and East Asia. 2002. Available online: http://www.iadb.org/sds/smeorhttp: //www.iadb.org/sds/ifm_s.htm (accessed on 10 September 2013).

(C) 2019 by the authors. Licensee MDPI, Basel, Switzerland. This article is an open access article distributed under the terms and conditions of the Creative Commons Attribution (CC BY) license (http://creativecommons.org/licenses/by/4.0/). 